\title{
Frugivory by birds on Schefflera morototoni (Araliaceae) in a Cerrado-Amazon Forest transition area, eastern Mato Grosso, Brazil
}

\author{
Keila Nunes PURIFICAÇÃO ${ }^{1,2 *}$, Márcia Cristina PASCOTTO², Adriana MOHR ${ }^{1}$, Eddie LENZA ${ }^{1}$ \\ 1 Universidade do Estado de Mato Grosso, Pós-Graduação em Ecologia e Conservação. Rodovia BR 158, km 148, Caixa Postal 08, 78.690-000, Nova Xavantina, Mato Grosso, Brasil. \\ ${ }^{2}$ Universidade Federal de Mato Grosso, Campus Universitário do Araguaia, Laboratório de Ornitologia. Avenida Valdon Varjão, $n^{0}$ 6.390, 78.600-000, Barra do Garças, Mato Grosso, \\ Brasil. \\ *Corresponding author: keilanunesbio@gmail.com
}

\section{ABSTRACT}

Schefflera morototoni fruits are important food source for neotropical frugivorous birds. The objectives of the present study were to record bird species that consumed fruits of $S$. morototoni in a forest in the transition Cerrado-Amazon Forest, Mato Grosso, Brazil and evaluate the potential of these bird species as seed dispersers of this plant species. During 31 observation hours, from November 1 to 5, 2011, 23 bird species were recorded consuming $S$. morototoni fruits. Out of these, 20 bird species were considered potential seed dispersers, as they swallow the fruits whole. The species consuming the greatest number of fruits were Aburria cujubi (24\% of total consumed fruits), Pteroglossus castanotis (18\%), Tangara palmarum (12\%), Patagioenas speciosa (11\%), Ramphastos toco (8\%), and Dacnis lineata (5\%). The species T. palmarum showed the highest visit frequency $(\mathrm{VF}=$ $1.51)$, followed by $P$. castanotis $(\mathrm{VF}=0.80)$, and $D$. lineata $(\mathrm{VF}=0.77)$. All bird species employed picking foraging method for removal of fruits and in 11 species (48\%) this method was the only one used. Agonistic interactions represented $13 \%$ of the total number of visits. Dacnis lineata received the highest number of attacks and P. castanotis and Pitangus sulphuratus were the more aggressive species. The high bird richness and the great number of consumed fruits indicated that the fruits of S. morototoni may be an important food resource for birds in the Cerrado-Amazon Forest transition.

KEYWORDS: Avifauna, ecotone, seed dispersal.

\section{Frugivoria por aves em Schefflera morototoni (Araliaceae) em área de transição Cerrado-Floresta Amazônica, leste de Mato Grosso, Brasil}

\begin{abstract}
RESUMO
Os frutos de Schefflera morototoni constituem importante fonte alimentar para aves frugívoras neotropicais. Os objetivos deste estudo foram registrar as espécies de aves que consumiram frutos de $S$. morototoni em uma floresta na transição CerradoFloresta Amazônica, Mato Grosso, Brasil e avaliar a potencialidade destas espécies de aves como dispersoras de sementes desta espécie de planta. Em 31 h de observaçôes compreendidas entre os dias 01 e 05 de novembro de 2011, registramos 23 espécies de aves consumindo os frutos de $S$. morototoni. Destas, 20 foram consideradas potenciais dispersoras de sementes por engolirem os diásporos inteiros. As espécies que consumiram maior número de frutos foram Aburria cujubi ( $24 \%$ do total de frutos consumidos), Pteroglossus castanotis (18\%), Tangara palmarum (12\%), Patagioenas speciosa (11\%), Ramphastos toco (8\%) e Dacnis lineata (5\%). A espécie T. palmarum apresentou maior frequência de visita (FV=1,51), seguida por P. castanotis $(\mathrm{FV}=0,80)$ e $D$. lineata $(\mathrm{FV}=0,77)$. Todas as espécies de aves empregaram a tática de forrageamento picking para remoçáo dos frutos e 11 espécies (48\%) utilizaram somente essa tática. Interaçôes agonísticas representaram 13\% do número total de visitas. Dacnis lineata foi a espécie que sofreu o maior número de agressōes e P. castanotis e Pitangus sulphuratus as espécies mais agressoras. A alta riqueza de aves e o elevado número de frutos consumidos mostrou que os frutos de $\mathrm{S}$. morototoni sáo recursos alimentares importantes para a avifauna na transição Cerrado-Floresta Amazônica.
\end{abstract}

PALAVRAS-CHAVE: Avifauna, dispersão de sementes, ecótono. 


\section{INTRODUCTION}

Frugivory is an ecologically significant interaction between plants and animals, in which plants provide food and frugivorous animals disperse the seeds away from the parent plant, something that can reduce predation, competition, and contamination by pathogens. Furthermore, it increases the gene flow of the dispersed plant species and helps maintain natural community integrity (Snow 1981; Howe and Smallwood 1982).

Up to $90 \%$ of tree species in tropical forests produce zoochorous fruits (Howe and Smallwood 1982; Puig 2008). Birds stand out among vertebrate dispersers due to their abundance, mobility, and the frequency with which they eat fruits (Pizo and Galetti 2010). The neotropical frugivorous avifauna is represented both by families whose most species are highly dependent on fruits $(\geq 75 \%)$ and by families with a smaller proportion of species dependent on fruits $(<25 \%)$ (Fadini and De Marco 2004).

The selection of fruits by birds is influenced by several plant attributes, including productivity, size, and color of the fruit, nutritional composition, presence of secondary chemical compounds, habitat structure, and vegetation composition (Staggemeier and Galetti 2007), as well as the bird's displacement distance to the foraging site (Levey et al. 1984). The evaluation of these attributes and their influence on the consumption of fruits allows an understanding of the processes of maintaining populations of fruiting plants and frugivorous birds.

Schefflera morototoni (Aubl.) Maguire et al. (Araliaceae), popularly known as mandiocáo or morototó in Brazil, is an evergreen, heliophilic tree species and it can reaching up to $35 \mathrm{~m}$. It occurs from Mexico to South Brazil and Northeast Argentina, especially in open forest formations (Carvalho 2003). Fruit production is continuous with prolonged maturation, though annual fruit volume and maturity may be influenced by climatic factors (Franco and Ferreira 2002). Infructescences are abundant, green-purplish, and occur at the ends of branches, this provides contrast with the leaves and make it easier for the birds to locate those (Saracco et al. 2005). Fruits are fleshy drupes with an average width of 4-6 $\mathrm{mm}$ and average length $6-10 \mathrm{~mm}$. They usually contain two flat seeds each up to $5 \mathrm{~mm}$ in length and with a $<1 \mathrm{~mm}$ thick protein- and lipid-rich pulp covering (Snow 1971). They are considered an important food source for forest birds throughout the plants Central and South America range (Snow 1981; Sick 1997; Saracco et al. 2005; Parrini et al. 2013). Given the above, our objectives were: (i) to record the species of birds that consumed Schefflera morototoni fruits; and (ii) to evaluate the potential of these species as dispersers of seeds from this plant species in a Cerrado-Amazon Forest transition area in the state of Mato Grosso, Brazil.

\section{MATERIALS AND METHODS}

We conducted the study in a forest fragment in Fazenda Destino ( $\left.12^{\circ} 51^{\prime} \mathrm{S}, 52^{\circ} 04^{\prime} \mathrm{W}\right)$, located some $30 \mathrm{~km}$ west of the town of Ribeirão Cascalheira, northeastern part of Mato Grosso state, Brazil. The region is characterized by semideciduous transitional forest at the Cerrado and Amazon Forest ecotone (Marimon et al. 2006). The climate is humid tropical: Aw type, according to Köppen's classification, and is characterized by two well-defined seasons, a dry (May to September) and a rainy season (October to April) (Silva et al. 2008). Average annual rainfall recorded at the Fazenda over the last thirteen years is $1,911 \mathrm{~mm}$ (data provided by Fazenda management). Altitude averages $330 \mathrm{~m}$ above sea level.

We observed two individuals Schefflera morototoni with an estimated height of 25-30 m during peak of fruit maturation. Trees were $1 \mathrm{~km}$ apart, both situated on the edge of a forest fragment, bordered by Brachiaria sp. (Poaceae) pasture. We conducted focal observations from 6:35 a.m. to 6:05 p.m., on five consecutive days, from 1 to 5 November, 2011. Observations were not continuous as rain occasionally interrupted the study. In total, we conducted 31 hours of focal observations at both individuals.

We evaluated the mode of consumption of fruit by birds, those that consumed fruit whole in situ or transported them from the site of the parent plant were considered potential seed dispersers (Howe and Smallwood 1982; Moermond and Denslow 1985). We recorded frugivory using an ad libitum methodology recommended by Pizo and Galetti (2010). We recorded all behaviors of individuals that consumed at least one fruit every visit. Birds that perched on the trees but did not consume any fruits were excluded from the analyses. From the arrival of an individual on the tree, we recorded: (i) the species of visiting bird, (ii) visit duration, (iii) the number of consumed fruits, (iv) how fruits were removed, (v) how birds processed fruits, and (vi) inter-intraspecific agonistic behaviors (when observed).

We used the terminology proposed by Moermond and Denslow (1985) for defining fruit-accessing behaviors: (i) picking - the bird catches the fruit landed, without extending its body or assuming a specific position, (ii) reaching - the bird extends its body below or above the perch to reach the fruit, (iii) hanging - the bird positions its whole body below the perch, with the ventral side upwards, and (iv) hovering - the bird catches the fruit during paused flight. We observed the avifauna and their feeding behaviors with the aid of binoculars $(8 \times 40 \mathrm{~mm})$ roughly $20 \mathrm{~m}$ apart of plant.

Taxonomic classification and nomenclature of bird species follows the Comitê Brasileiro de Registros Ornitológicos (CBRO 2014). For the plant species we used the Lista de 
Espécies da Flora do Brasil (2014). Classification of bird species diets followed Sick (1997), and Vieira et al. (2013).

We calculated the visit frequency (VF) for each bird species with at least one complete observation (bird was observed from its arrival on the plant until its departure) dividing the total number of visits of a particular bird species by total observation hours (Gondim 2001). We obtained the rate of consumption by each species by dividing the number of fruits consumed by each species by the total hours of observation (Pascotto 2006). We used Spearman's Correlation test to evaluate whether a correlation existed between number of fruits consumed and duration of visits. To verify whether fruit consumption differed among bird species we applied the nonparametric KruskalWallis test (Zar 1999). We performed statistical analyzes with the software Paleontological Statistics (PAST), version 2.15 (Hammer et al. 2001).

\section{RESULTS}

We recorded 164 visits $(5.29 \pm 0.35$ visits/hour $)$ and the consumption of 2,426 fruits $(78.25 \pm 5.02$ fruits/hour). We observed 23 bird species, belonging to five orders and 12 families, consuming $S$. morototoni fruits. Among them, 14 species belonged to the Order Passeriformes. The most strongly represented families in terms of number of species and visits were Thraupidae (6 species, 75 visits), Ramphastidae (4, $34)$, Picidae $(2,15)$, Tyrannidae $(2,14)$, and Icteridae $(2,2)$. Other families (Cracidae, Columbidae, Psittacidae, Tityridae, Contigidae, Turdidae, and Fringillidae) were represented by only one species each (Table 1 ).

Twenty bird species ( $87 \%$ of the total) were regarded as potential seed dispersers of $S$. morototoni, since they swallowed fruits whole enabling propagule dispersal away from the parent plant. Only Forpus xanthopterygius (Psittacidae), which crushed the seed, and Tangara nigrocincta, and Tangara cyanicollis (Thraupidae), which consumed only the pulp, were not considered dispersers of seeds. Patagioenas speciosa (Columbidae), Melanerpes cruentatus (Picidae), Myiozetetes cayanensis (Tyrannidae), Ramphocelus carbo, Tangara palmarum, Tersina viridis, Dacnis lineata (Thraupidae), and Cacicus cela (Icteridae) were observed consuming whole fruits and only the pulp. Therefore, we consider these species as potential dispersers, since they had at least one feeding bout involving the intake of whole seeds.

Fruit consumption significantly differed between bird species (Kruskal-Wallis $\mathrm{H}={ }_{(22, \mathrm{~N}=164)}=81.250 ; \mathrm{p}<$ 0.001 ). Those with the presenting a highest percentage of consumption were Aburria cujubi (Cracidae) (24\% of total), Pteroglossus castanotis (Ramphastidae) (18\%), T. palmarum (12\%), P. speciosa (11\%), Ramphastos toco (Ramphastidae) $(8 \%)$, and $D$. lineata $(5 \%)$. The species with the highest visit frequency was $T$. palmarum $(\mathrm{VF}=1.51$ ), which, in most cases, occurred in flocks of eight to 12 individuals. Other frequently visiting species were $P$. castanotis $(\mathrm{VF}=0.80)$, followed by $D$. lineata $(\mathrm{VF}=0.77), M$. cruentatus $(\mathrm{VF}=0.45)$, and $M$. cayanensis $(\mathrm{VF}=0.29)$ (Table 1$)$.

Species with a predominantly frugivorous diets accounted for $48 \%$ of consumption of $S$. morototoni fruits, followed by omnivorous (39\%) and insectivorous (13\%) species. The bird species which made only one visit were $F$ xanthopterygius, Dryocopus lineatus (Picidae), T. nigrocincta, T. cyanicollis, C. cela, Icterus pyrrhopterus (Icteridae), and Euphonia rufiventris (Fringillidae), and they accounted for $30 \%$ of the total.

We found a correlation between fruit consumption and duration of visit $(\mathrm{r}=0.878 ; \mathrm{p}<0.001)$. Among the potential seed dispersing species, large frugivores, such as $A$. cujubi, $P$. speciosa, R. toco, and Pteroglossus inscriptus (Ramphastidae) accounted for $70 \%$ of the total consumption and had longer visits, whereas small frugivorous birds, such as $M$. cruentatus, T. palmarum, and D. lineata, accounted for shorter visits (less than four minutes), although these were more frequent. Aburria cujubi, P. inscriptus, $R$. toco, Tityra semifasciata (Tityridae), and T. palmarum defecated on plants while feeding. The same individual $A$. cujubi which defecated on the plant, as well as a $R$. toco individual, also regurgitated.

Pteroglossus castanotis and Pitangus sulphuratus (Tyrannidae) were the most aggressive species ( $\mathrm{n}=3$ attacks), and $D$. lineata the most attacked species $(n=6)$. Interspecific agonistic encounters $(n=12)$ predominated over intraspecific encounters $(\mathrm{n}=8)$. Intraspecific agonistic encounters were recorded for A. cujubi, P. castanotis, P. sulphuratus (n =2), $M$. cayanensis $(\mathrm{n}=2), T$. viridis, and $D$. lineata, always involving only one individual. We observed the following interspecific agonistic encounters (aggressor species listed first): Cotinga cayana (Cotingidae) and T. palmarum, P. speciosa and M. cruentatus, T. palmarum and D. lineata, T. palmarum and T. viridis, T. cyanicollis and D. lineata, C. cela and T. palmarum, M. cruentatus and T. palmarum, P. sulphuratus and $M$. cruentatus, M. cruentatus and T. palmarum, Turdus fumigatus (Turdidae) and D. lineata, and $P$. castanotis and D. lineata (n $=2$ ). We recorded a positive social interaction between two T. palmarum individuals that were foraging together, where one individual offered a fruit to another.

The foraging method most frequently used by birds for removing the fruits was picking, employed by all species and used as the sole means by $48 \%$ of them. Large frugivores which are highly dependent on fruits mainly used this method. Pteroglossus castanotis, M. cayanensis, T. palmarum, and $D$. lineata all used the catching method. The hovering method was mainly employed by insectivorous species, such as T. semifasciata, P. sulphuratus, and $M$. cayanensis, which employ similar tactics for catching insects in flight. The least frequently used method was hanging, but it was the most frequent method employed by T. palmarum and P. castanotis, species which also used other methods (Table 2). 
Table 1. Bird species which consumed Schefflera morototoni (Araliaceae) fruits during 31 observation hours in a Cerrado-Amazon transition forest patch near the town of Ribeirão Cascalheira, Mato Grosso, Brazil. FRU = frugivorous; INS = insectivorous; OMN = omnivorous; PD = potential disperser; ND = not disperser. §Sick (1997); *Vieira et al. (2013).

\begin{tabular}{|c|c|c|c|c|c|c|c|}
\hline Taxon & $\begin{array}{l}\text { Number } \\
\text { of visits }\end{array}$ & $\begin{array}{l}\text { Duration of visits } \\
\text { (seconds) }\end{array}$ & Diet & $\begin{array}{l}\text { Number fruits } \\
\text { consumed }\end{array}$ & Fruits/visit & $\begin{array}{c}\text { Visit } \\
\text { frequency }\end{array}$ & $\begin{array}{c}\text { Potential } \\
\text { dispersion }\end{array}$ \\
\hline \multicolumn{8}{|l|}{ Cracidae } \\
\hline Aburria cujubi (Pelzeln, 1858) & 6 & $647 \pm 628.8$ & FRU & 593 & $98.8 \pm 82.6$ & 0.19 & PD \\
\hline \multicolumn{8}{|l|}{ Columbidae } \\
\hline Patagioenas speciosa (Gmelin, 1789) & 4 & $413 \pm 297$ & FRU & 273 & $68.2 \pm 41.4$ & 0.12 & PD \\
\hline \multicolumn{8}{|l|}{ Psittacidae } \\
\hline Forpus xanthopterygius (Spix, 1824) & 1 & 340 & FRU* & 4 & 4 & 0.03 & ND \\
\hline \multicolumn{8}{|l|}{ Ramphastidae } \\
\hline Ramphastos toco Statius Muller, 1776 & 5 & $221 \pm 55.4$ & FRU & 191 & $38.2 \pm 18.9$ & 0.16 & PD \\
\hline Pteroglossus inscriptus Swainson, 1822 & 2 & $451 \pm 9.9$ & FRU* & 65 & $32.5 \pm 34.6$ & 0.06 & PD \\
\hline Pteroglossus bitorquatus Vigors, 1826 & 2 & $381.5 \pm 246.8$ & $\mathrm{FRU}^{\S}$ & 36 & $18 \pm 7.07$ & 0.06 & PD \\
\hline Pteroglossus castanotis Gould, 1834 & 25 & $215.7 \pm 270.9$ & $\mathrm{FRU}^{\S}$ & 446 & $17.76 \pm 13.86$ & 0.80 & PD \\
\hline \multicolumn{8}{|l|}{ Picidae } \\
\hline Melanerpes cruentatus (Boddaert, 1783) & 14 & $121.2 \pm 58$ & INS & 92 & $6.6 \pm 3.9$ & 0.45 & PD \\
\hline Dryocopus lineatus (Linnaeus, 1766) & 1 & 445 & INS* & 47 & 47 & 0.03 & PD \\
\hline \multicolumn{8}{|l|}{ Tityridae } \\
\hline Tityra semifasciata (Spix, 1825) & 3 & $90.3 \pm 48.8$ & $\mathrm{INS}^{\S}$ & 16 & $5.33 \pm 3.05$ & 0.09 & PD \\
\hline \multicolumn{8}{|l|}{ Cotingidae } \\
\hline Cotinga cayana (Linnaeus, 1766) & 3 & $204.3 \pm 98.6$ & $\mathrm{FRU}^{\S}$ & 45 & $15 \pm 1.73$ & 0.09 & PD \\
\hline \multicolumn{8}{|l|}{ Tyrannidae } \\
\hline Pitangus sulphuratus (Linnaeus, 1766) & 5 & $142.2 \pm 56.9$ & OMN* & 37 & $7.4 \pm 2.6$ & 0.16 & PD \\
\hline Myiozetetes cayanensis (Linnaeus, 1766) & 9 & $83.3 \pm 36.7$ & OMN & 45 & $5 \pm 2.6$ & 0.29 & PD \\
\hline \multicolumn{8}{|l|}{ Turdidae } \\
\hline Turdus fumigatus Lichtenstein, 1823 & 2 & $122 \pm 36.8$ & $\mathrm{OMN}^{*}$ & 18 & $9 \pm 1.41$ & 0.06 & PD \\
\hline \multicolumn{8}{|l|}{ Thraupidae } \\
\hline Ramphocelus carbo (Pallas, 1764) & 2 & $156 \pm 97.6$ & $\mathrm{OMN}^{*}$ & 14 & $7 \pm 5.65$ & 0.06 & PD \\
\hline Tangara palmarum (Wied, 1823) & 47 & $107.3 \pm 64.3$ & OMN* & 293 & $6.34 \pm 4.29$ & 1.51 & PD \\
\hline Tangara nigrocincta (Bonaparte, 1838) & 1 & 203 & FRU & 12 & 12 & 0.03 & ND \\
\hline Tangara cyanicollis (d'Orbigny e Lafresnaye, 1837) & 1 & 53 & FRU & 3 & 3 & 0.03 & ND \\
\hline Tersina viridis (Illiger, 1811) & 4 & $174 \pm 120.1$ & OMN & 14 & $3.5 \pm 1.29$ & 0.12 & PD \\
\hline Dacnis lineata (Gmelin, 1789) & 24 & $118.4 \pm 102.7$ & OMN§ & 137 & $5.7 \pm 2.95$ & 0.77 & PD \\
\hline \multicolumn{8}{|l|}{ Icteridae } \\
\hline Cacicus cela (Linnaeus, 1758) & 1 & 368 & OMN§ & 33 & 33 & 0.03 & PD \\
\hline Icterus pyrrhopterus (Vieillot, 1819) & 1 & 157 & OMN§ & 9 & 9 & 0.03 & PD \\
\hline \multicolumn{8}{|l|}{ Fringillidae } \\
\hline Euphonia rufiventris (Vieillot, 1819) & 1 & 43 & FRU & 3 & 3 & 0.03 & PD \\
\hline
\end{tabular}


Table 2. Total number of Schefflera morototoni (Araliaceae) fruits consumed by birds at Ribeirão Cascalheira, Mato Grosso, Brazil (all fruit gaining methods combined).

\begin{tabular}{lcccc}
\hline Species & Picking & Reaching & Hanging & Hovering \\
\hline Aburria cujubi & 578 & 0 & 08 & 07 \\
Patagioenas speciosa & 273 & 0 & 0 & 0 \\
Ramphastos toco & 191 & 0 & 0 & 0 \\
\hline Pteroglossus inscriptus & 65 & 0 & 0 & 0 \\
\hline Pteroglossus bitorquatus & 36 & 0 & 0 & 0 \\
\hline Pteroglossus castanotis & 415 & 11 & 14 & 06 \\
\hline Melanerpes cruentatus & 84 & 05 & 03 & 0 \\
\hline Dryocopus lineatus & 47 & 0 & 0 & 0 \\
Forpus xanthopterygius & 04 & 0 & 0 & 0 \\
\hline Tityra semifasciata & 02 & 03 & 02 & 09 \\
Cotinga cayana & 41 & 0 & 04 & 0 \\
\hline Pitangus sulphuratus & 10 & 05 & 0 & 22 \\
\hline Myiozetetes cayanensis & 09 & 02 & 05 & 29 \\
Turdus fumigatus & 18 & 0 & 0 & 0 \\
Cacicus cela & 33 & 0 & 0 & 0 \\
\hline Icterus pyrrhopterus & 07 & 02 & 0 & 0 \\
Ramphocelus carbo & 14 & 0 & 0 & 0 \\
\hline Tangara palmarum & 203 & 40 & 44 & 06 \\
\hline Tangara nigrocincta & 12 & 0 & 0 & 0 \\
\hline Tangara cyanicollis & 02 & 0 & 0 & 01 \\
\hline Tersina viridis & 10 & 02 & 0 & 02 \\
\hline Dacnis lineata & 103 & 25 & 07 & 02 \\
\hline Euphonia rufiventris & 03 & 0 & 0 & 0 \\
\hline
\end{tabular}

\section{DISCUSSION}

Schefflera morototoni stands out among species the Araliaceae with regard to frugivory by birds, since it has nutritious and small fruits, which favor consumption both by small and large frugivores (Snow 1981). This indicates that $S$. morototoni is a generalist species with respect to its fruit dispersal of (Howe and Smallwood 1982), as it produces a large amount of small fruits consumed by specialist frugivores, such as A. cujubi, and generalist frugivores, such as $P$. sulphuratus and T. fumigatus. The production of attractive fruits to generalist frugivorous species is probably a strategy of the plant to favor the spread of its fruits in a variety of environments. This facilitates the colonization of new areas by frugivores that frequent preserved and altered areas (Manhães et al. 2003).

The fruits of $S$. morototoni are easy to remove and ingest, because there is no physical barrier that prevents or hinders their consumption by most birds. Fruits lacking capsules, such as $S$. morototoni, are more rapidly consumed by birds, and this makes visits shorter (Coates-Estrada and Estrada 1988). This reduces the possibility that the frugivore's foraging bout will be extensive, which decreases the changes of seeds being deposited close to their parent plant (Takahashi and Kamitani 2004).
Members of the Thraupidae are among the neotropical frugivorous birds most suited to seed dispersal (Sick 1997) and primarily act as dispersers of small fruits whose seeds are not easily removed from the pulp (Francisco and Galetti 2002). Tangara palmarum was the most frequently visiting species, and was third in terms of number of $S$. morototoni fruits consumed. Although Sick (1997) stated that some species of tanagers, as T. palmarum, are not good seed dispersers, due to their behavior of mashing the fruits and letting the seeds fall under the parent plant, this species was regarded as a potential seed disperser of $S$. morototoni. The behavior of swallowing the whole fruit was more frequent than discarding seeds. The results obtained for $T$. nigrocincta and $T$. cyanicollis are among the exceptions reported by Sick (1997), since these species were always observed discarding the seeds. On the other hand, species which discarded seeds, especially tanagers or species which dropped fruits, such as $D$. lineatus, can contribute to secondary dispersion.

Aburria cujubi showed higher consumption rate in relation to other species. On the other hand, it was the species with the longest visits, so that individuals of this species to defecate and regurgitate during foraging. However, we cannot neglect the importance of this species as a seed disperser, because this species was responsible for the largest amount of $S$. morototoni fruits consumed (24\% of the total removed). Moreover, its seed dispersal efficacy was noted by Muñoz and Kattan (2007), who concluded that species of the Penelopinae subfamily play a significant role as seed dispersers, especially considering that seeds remain intact throughout the whole digestive tract of birds of this group.

The high number of specialist frugivores visiting $S$. morototoni was because of members of the Ramphastidae, since toucans, besides being primarily frugivorous (Galetti et al. 2000), are large appreciators of S. morototoni fruits (Sick 1997; Parrini et al. 2013). The Cotingidae family, represented in this study by $C$. cayana, is among the most efficient Neotropical bird families with regard to seed dispersal. According to Snow (1971), the seeds which are swallowed by species of this family do not suffer reduced viability. Indeed, they have higher germination rates.

The use of different methods to obtain fruits plays an important role in the frugivory and seed dispersal processes. This allows the removal of fruits from different portions of the same tree (Manhães et al. 2003). For instance, large birds that used the picking method were not effective at removing fruits of $S$. morototoni from the ends of the branches, whereas, birds such as P. sulphuratus and T. palmarum captured these fruits using the hovering method. Small birds, such as D. lineata, in turn, reached fruits at the tips of branches without hovering flight, a result of lower body mass. 
Interspecific agonistic interactions represent a negative component in seed dispersal, since aggression can hinder fruit consumption by potential dispersers (Francisco and Galetti 2001). In this study, the frequency of agonistic interactions was low when compared to the total number of visits (13\%), and is therefore not significant enough to negatively affect the process of seed dispersal of $S$. morototoni. Dacnis lineata, the most attacked species, was not considered as an efficient disperser, since most feeding bouts this species discarded seeds under the plant. In turn, $P$. castanotis and $P$. sulphuratus, the most aggressive species, were efficient dispersers. Thus, agonistic interactions between disperser birds do not reduce reproductive success of $S$. morototoni.

The number of bird species consuming $S$. morototoni fruits, both in this study and in that of Parrini et al. (2013), was high when compared with studies of other plant species using similar methodologies and sampling efforts greater that the current study (e.g. Francisco and Galetti 2001; 2002; Melo et al. 2003). The high richness of bird species with dispersal potential, different specific strategies for obtaining fruits and the high consumption of fruits suggest the existence of strong interactions between $S$. morototoni and the local frugivorous avifauna. Plants producing numerous, small, and nutritious fruits, such as $S$. morototoni, attract both large frugivorous birds, which have a high nutritional demand, and small frugivorous birds, which are able to swallow the whole fruits and, thus, disperse the seeds away from the parent plant (Snow 1981; Jordano et al. 2007).

\section{CONCLUSIONS}

In this study, we showed that $S$. morototoni is important food source for several bird species in the Cerrado-Amazon Forest transition region. In turn, the diversity of dispersal agents ensures the reproductive success this plant, as evidenced by the wide distribution of this species throughout Central America and South America.

\section{ACKNOWLEDGEMENTS}

To the Programa de Apoio à Pós-graduaçáo (PROAP)/ Coordenação de Aperfeiçoamento de Pessoal de Nível Superior (CAPES) for the financial support. To the Mr. Marcio Evandro Coninck Monteiro and José Schreiner Miri, manager and owner of Fazenda Destino, respectively, for allowing the conduction of this study at the property.

\section{REFERENCES}

Carvalho, P. E. R. 2003. Espécies Arbóreas Brasileiras. Embrapa Florestas, Colombo, Paraná, 2003, 1.039p.

CBRO, 2014. Lista das aves do Brasil. 11a ed. (http://www.cbro. org.br). Accessed on 13/06/2014.
Coates-Estrada, R.; Estrada, A. 1988. Frugivory and seed dispersal in Cymbopetalum baillonii (Annonaceae) at Los Tuxtlas, Mexico. Journal of Tropical Ecology, 4: 157-172.

Fadini, R. F.; De Marco, Jr. P. 2004. Interaçóes entre aves frugívoras e plantas em um fragmento de Mata Atlântica de Minas Gerais. Ararajuba, 12: 97-103.

Francisco, M. R.; Galetti, M. 2001. Frugivoria e dispersão de sementes de Rapanea lancifolia (Myrsinaceae) por aves numa área de cerrado do Estado de São Paulo, sudeste do Brasil. Ararajuba, 9: 13-19.

Francisco, M. R.; Galetti, M. 2002. Aves como potenciais dispersores de sementes de Ocotea pulchella Mart. (Lauraceae) numa área de vegetação de cerrado do sudeste brasileiro. Revista Brasileira de Botânica, 25: 11-17.

Franco, E. T. H.; Ferreira, A. G. 2002. Tratamentos pré-germinativos em sementes de Didymopanax morototoni (Aubl.) Dcne. et Planch. Ciência Florestal, 12: 1-10.

Galetti, M.; Laps, R.; Pizo, M. A. 2000. Frugivory by toucans (Ramphastidae) at two altitudes in the Atlantic Forest of Brazil. Biotropica, 32: 842-850.

Gondim, M. J. C. 2001. Dispersão de sementes de Trichilia spp. (Meliaceae) por aves em um fragmento de mata mesófila semidecídua, Rio Claro, SP, Brasil. Ararajuba, 9: 101-112.

Hammer, O.; Harper, A. T. D.; Ryan, P. D. 2001. Past: Paleontological Statistics Software Package for Education and Data Analysis. Palaeontologia Electronica, 4: 1-9.

Howe, H. F.; Smallwood, J. 1982. Ecology of seed dispersal. Annual Review of Ecology and Systematics, 13: 201-228.

Jordano, P.; Garcia, C.; Godoy, J. A.; Garcia-Castaño, J. L. 2007. Differential contribution of frugivores to complex seed dispersal patterns. Proceedings of the National Academy of Sciences of the United States of America, 104: 3278-3282.

Levey, D. J.; Moermond, T. C.; Denslow, J. S. 1984. Fruit choice in Neotropical birds: the effect of distance between fruits on preference patterns. Ecology, 65: 844-850.

Lista de Espécies da Flora do Brasil, 2014. (http://floradobrasil.jbrj. gov.br/). Accessed on 02/05/ 2014.

Manhães, M. A.; Assis, L. C. S.; Castro, R. M. 2003. Frugivoria e dispersáo de sementes de Miconia urophylla (Melastomataceae) por aves em um fragmento de Mata Atlântica secundária em Juiz de Fora, Minas Gerais, Brasil. Ararajuba, 11: 173-180.

Marimon, B. S.; Lima, E. S.; Duarte, T. G.; Chieregatto, L. C.; Ratter, J. A. 2006. Observations on the vegetation of northeastern Mato Grosso, Brazil. IV. An analysis of the Cerrado-Amazonian Forest ecotone. Edinburgh Journal of Botany, 63: 323-341.

Melo, C.; Bento, E. C.; Oliveira, P. E. 2003. Frugivory and dispersal of Faramea cyanea (Rubiaceae) in cerrado woody plant formations. Brazilian Journal of Biology, 63: 75-82.

Moermond, T. C.; Denslow, J. S. 1985. Neotropical avian frugivores: patterns of behavior, morphology, and nutrition, with consequences for fruit selection. Ornithological Monographs, 36: 865-897.

Muñoz, M. C.; Kattan, G. H. 2007. Diets of cracids: how much do we know? Ornitologia Neotropical, 18: 21-36. 
Parrini, R.; Raposo, M. A.; Del Hoyo, J.; Silva, A. R. 2013. Schefflera morototoni (Araliaceae) como importante recurso alimentar para as aves durante a estação seca na Amazônia central. Cotinga, 35: 1-4.

Pascotto, M. C. 2006. Avifauna dispersora de sementes de Alchornea glandulosa (Euphorbiaceae) em uma área de mata ciliar no estado de São Paulo. Revista Brasileira de Ornitologia, 14: 291-296.

Pizo, M. A.; Galetti, M. 2010. Métodos e perspectivas do estudo da frugivoria e dispersão de sementes por aves. In: Accordi, I.; Straube, F. C.; Von Matter, S. (Org.). Ornitologia e Conservaçâa: Ciência Aplicada, Técnicas de Pesquisa e Levantamento. Technical Books, Rio de Janeiro, Rio de Janeiro, p.492- 504.

Puig, H. 2008. A floresta tropical úmida. Editora UNESP: Imprensa Oficial do Estado de São Paulo, São Paulo, 2008, 496p.

Saracco, J. F.; Collazo, J. A.; Groom, M. J.; Carlo, T. A. 2005. Crop size and fruit neighborhood effects on bird visitation to fruiting Schefflera morototoni trees in Puerto Rico. Biotropica, 37: 81-87.

Sick, H. 1997. Ornitologia Brasileira: uma introduçâo. Nova Fronteira, Rio de Janeiro, 1997, 912p.

Silva, F. A. M.; Assad, E. D.; Evangelista, B. A. 2008. Caracterização climática do Bioma Cerrado. In: Sano, S. M.; Almeida, S.
P.; Ribeiro, J. F. (Ed.). Cerrado: ecologia e flora. v.1. Embrapa Cerrados, Brasília, Distrito Federal, p.69-88.

Snow, D. W. 1971. Evolutionary aspects of fruit-eating by birds. Ibis, 113: 194-202.

Snow, D. W. 1981. Tropical frugivorous birds and their food plants: a world survey. Biotropica, 13: 1-14.

Staggemeier, V. G.; Galetti, M. 2007. Impacto humano afeta negativamente a dispersão de sementes de frutos ornitocóricos: uma perspectiva global. Revista Brasileira de Ornitologia, 15: 281-287.

Takahashi, K.; Kamitani, T. 2004. Effect of dispersal capacity on forest plant migration at a landscape scale. Journal of Ecology, 92: 778-785.

Vieira, F. M.; Purificação, K. N.; Castilho, L. S.; Pascotto, M. C. 2013. Estrutura trófica da avifauna de quatro fitofisionomias de Cerrado no Parque Estadual da Serra Azul. Ornithologia, 5: 43-57.

Zar, J. H. 1999. Biostatistical analysis. Prentice-Hall, New York, 1999, 944 p.

Recebido em 20/06/2014

Aceito em 06/08/2014 
